Meta

Journal des tradlucteurs

Translators' Journal

\title{
Scott, C. (2006): Translating Rimbaud's Illuminations, Exeter, Great Britain, University of Exeter Press, 328 p.
}

\section{Daniel Sloate}

Volume 52, numéro 3, septembre 2007

URI : https://id.erudit.org/iderudit/016744ar

DOI : https://doi.org/10.7202/016744ar

Aller au sommaire du numéro

\section{Éditeur(s)}

Les Presses de l'Université de Montréal

\section{ISSN}

0026-0452 (imprimé)

1492-1421 (numérique)

Découvrir la revue

Citer ce compte rendu

Sloate, D. (2007). Compte rendu de [Scott, C. (2006): Translating Rimbaud's Illuminations, Exeter, Great Britain, University of Exeter Press, 328 p.] Meta, 52(3), 582-583. https://doi.org/10.7202/016744ar

Ce document est protégé par la loi sur le droit d'auteur. L'utilisation des services d'Érudit (y compris la reproduction) est assujettie à sa politique d'utilisation que vous pouvez consulter en ligne.

https://apropos.erudit.org/fr/usagers/politique-dutilisation/
Cet article est diffusé et préservé par Érudit.

Érudit est un consortium interuniversitaire sans but lucratif composé de l'Université de Montréal, l'Université Laval et l'Université du Québec à Montréal. Il a pour mission la promotion et la valorisation de la recherche. https://www.erudit.org/fr/ 


\section{Sсотт, C. (2006): Translating Rimbaud's Illuminations, Exeter, Great Britain, University of Exeter Press, 328 p.}

This book is a sequel to the author's Translating Baudelaire, and expands on its translational techniques. The different ways a translator can explore literary connections and experimental writing are discussed, sometimes at considerable length and with ingenious details that are quite thought-provoking. The author's ideas are novel and call upon the translator to exploit more fully what he calls "the space of the page," and to attempt a less-linear approach to the original text.

These ideas lead the author down new paths, making distinctions that are more academic than practical, like insisting a trifle heavily on the difference (there is one, granted) between a metalinguistic approach to translation and a metalanguage one. But his suggestions about the graphic importance of the printed page are fascinating if a trifle annoying. Example: in his proposed experimental translation of Mystique, the author changes font four or five times, uses upper cases within the printed line only to switch to lower cases when the emphasis he wants is less than that suggested by upper case letters. Punctuation, re-arrangement of sentences, dangling fragments of text are all used to novel effect, although, as I mentioned, the overall effect is somewhat annoying and certainly distracting. He complains about the extreme attention paid by translators of Rimbaud to the signified at the expense of the signifier, but has he not committed the same excess in his "experiments" with respect to the signifier?

The author is more pertinent when examining the age-old question, "What is a good translation?" He observes that translation has a penchant for ignoring the literary world it inhabits "in order to occupy only the world projected by the ST, yet without pursuing a policy of thoroughgoing historicism" (p. 33). What is important, and Clive Scott's point here is refreshing and novel, is the author's suggestion that certainly "conventional" translation techniques are necessary to anchor the ST in space and time, but also it is important to imagine the Illuminations themselves as works in progress, unstable, non-definitive in form and content. Once this hypothesis is accepted, then the translator should feel free to experiment, to stress certain emphatic passages, to downplay other, less strident passages. And this freedom should entail a re-utilization of the page by means of punctuation, shifting fonts, various uses of graphics to put certain passages into relief. The author insists this experimentation, this freedom, is not a license to indulge one's own vagaries, one's own idiosyncratic approach to the ST, but rather to put the ST itself, in all its inherent uniqueness, indelibly into, and beyond, the TT by means of these techniques of emphasis, graphics and intralinguistic epiphanies the adventurous (and modern!) translator should have at his disposal.

Scott delves into a fascinating examination of the Rimbaldian prose poem and has some good points to make. Certainly the most pertinent is his assertion that "the Rimbaldian text does not make sense of itself, by virtue of structural indices." His point is well taken when he stresses that any "sense" is created through the poem's acoustic components, its subtle play of rhythm and "the connotative affinities within it." Scott seems to include tenses in shifts of rhythm and this is so if one allows for the play of tenses as a shifting in the rhythm of time. He falls back on the traditional metric schemes for most of the rhythmic structures, however, sometimes with telling effect: his "experiments" with "Dawn" are quite effective, with shifts between iambic and anapest schemes to bring out what he terms rhythmic phrases "probably operating at a half-heard level."

In conclusion, Clive Scott tells us the act of decoding meaning destroys what he calls "textual resistance," the desire of language to achieve its own "proliferation." Scott's own words sum up his position best: 
The reader [...] borrows the tactics of the translator, disassembling, reassembling, developing, highlighting sounds, grammar and syntax, so that the text is invested with significance rather than being plundered for its meaning.

In a sense, both the translator, as reader of the ST, and the readers of TTs, need to be readers who do not understand, who do not wish to understand. (p. 261)

Daniel Sloate University of Montreal, Montreal, Canada 